\title{
FDI and the costs of contract enforcement in developing countries
}

\author{
John S. Ahlquist · Aseem Prakash
}

Published online: 29 May 2009

(C) The Author(s) 2009. This article is published with open access at Springerlink.com

\begin{abstract}
This article examines the relationship between foreign direct investment and host countries' contracting institutions, the rule systems which govern commercial transactions between private actors. Given their liability of foreignness and costly exit options, we suggest that multinational corporations have incentives to influence the formal contracting environment in host countries. Further, host governments are more likely to respond to multinationals' wishes when they are more dependent on foreign capital markets. We draw on the World Bank's Lex Mundi dataset (Djankov et al. 2003) on microlevel contracting environment for private actors. Our analysis of a cross section of 98 developing countries suggests that FDI is associated with lower contract enforcement costs, particularly when the host country is more indebted.
\end{abstract}

Keywords Contract enforcement $\cdot$ Foreign investment $\cdot$ Globalization

\section{Introduction}

Policy Sciences seek to analytically examine concrete economic, social, and political challenges to help policy maker arrive at sound decisions. In contemporary times, an important task for policy makers is to develop strategies to meet the challenges posed and opportunities offered by economic globalization. The term 'globalization' is a contested one and there is a virtual academic industry examining various dimensions of globalization (Prakash and Hart 1999; Held and McGrew 2003). In this article, we view economic globalization as the increasing levels, depth, and speed of cross-border economic, social,

\section{J. S. Ahlquist}

Institute for Research on Labor and Employment, University of California, Los Angeles, Los Angeles, CA, USA

e-mail: jahlquist@irle.ucla.edu

\section{A. Prakash $(\bowtie)$}

Department of Political Science, University of Washington, Seattle, WA, USA

e-mail: aseem@u.washington.edu 
and ideational flows and linkages. An important consequence of getting embedded in a global economy is that the domestic policy realm begins to get influenced by foreign actors and by developments in foreign countries. With globalization, the domestic-international divide for policy makers tends to become less pronounced. The recent economic crisis attests to the serious implications for the domestic economy of cross-border economic linkages, especially the consequences of integrating with global banking and capital markets. This particular genre of global economic integration has extracted a heavy toll across the world. Economies, whose banking or insurance companies' asset portfolios had exposure to subprime mortgages (or securities in which they were bundled together), have suffered. It would not be an exaggeration to say that there exists deep skepticism about the benefits of economic globalization.

Yet, it would be a policy folly to take an undifferentiated (negative) view of economic globalization. Even in these troubled times, not all forms of economic globalization necessarily have perverse consequences for the domestic economy. For both policy and analytical reasons, it is important to differentiate financial globalization from trade-induced and foreign direct investment (FDI)-induced economic globalization, to examine their varying consequences for the domestic economy. This article focuses on economic integration via the agency of multinational corporations (the actors which undertake FDI), to examine its relationship with domestic contracting institutions. In doing so, we offer some evidence that the contributions of FDI to the host country exceed the visible economic ones such as increased capital formation, employment, improved balance of payment, and technological upgradation (Moran et al. 2005). We highlight the positive consequences of FDI for the host country's institutional environment, especially the contracting environment which provides the foundations for commercial transaction among private actors. We are interested in studying the institutional environment for private contracts: that is, contracts between private commercial actors (North 1981; Acemoglu and Johnson 2005) not private actors and the government which has been the focus of much of property rights literature (North and Weingast 1989; Olson 2000). The question we pose is the following: are FDI inflows associated with low cost (formal) contract enforcement between private actors in the host economies?

Policymakers should pay close attention to the contracting environment because it has an important implication for economic growth (Acemoglu and Johnson 2005). This is particularly important for developing countries which tend to have varying levels of contract enforcement. When enforcing contracts are expensive, market actors see their contracting costs increase and their profits dissipate. As North (1990) and others have pointed out, these costs are an important predictor of economic growth: lower the costs, higher the growth. Any policy change that leads to the lowering of contracting costs should be beneficial for economic growth, a goal most policy scientists would agree is worth pursuing. We find evidence that FDI can serve as a useful agent in this regard. The implication is that policy makers should view the benefits and costs of integrating with the global economy not only in terms of the direct consequences but also in terms of the indirect consequences for domestic policy institutions.

The novelty of this article is that we bring in a new dimension to wider discussion on the domestic policy and institutional consequences of economic globalization, specifically FDI-induced globalization. Theoretically, we argue that given its liability of foreignness and its inability to quickly "vote with its feet," FDI has the incentive to persuade host governments to supply a low cost contract enforcement environment. Empirically, we find that higher levels of FDI inflows are associated with low cost contract dispute settlement environment. 
Policies provided by public institutions have characteristics of public goods in that they are non-rival and non-excludable. Because contracting institutions have public good characteristics, the benefits of creating such institutions can be reaped by all commercial actors in the country. This potentially lowers contracting costs for all actors, not just multinational corporations.

A contract can be viewed as an agreement between two or more actors. These actors can be individuals, firms, non-profit organizations, or government agencies. This agreement pertain "to do, or to refrain from doing, a particular thing in exchange for something of value. If one side fails to live up to his/her/its part of the bargain, there's a "breach" and certain remedies for solving the differences are available." ${ }^{1}$ Most commercial transactions, especially business-to-business transactions, take place via contracts. Indeed, commercial contracts can be viewed as the foundational pillars, the building blocks, for market-based exchanges.

Contracts need to be monitored and enforced; otherwise, as Hobbes had observed, "covenants without swords are mere words." One pressing problem in developing countries is that contracts between commercial actors are costly to enforce. In such situations, some contracting actors might have incentives not to honor the contract or what is described as the problem of opportunism. With the perception of poor or costly enforcement and the fear of being subjected to opportunistic exploitation, commercial actors tend to have fewer incentives to undertake long-term investments or to undertake transactions with actors outside their ethnic network. This hurts commerce across time, space, and ethnicity. Actors cannot tap economies of scale. The end result is that economic development suffers.

How to extricate an economy from such situations? An institutional perspective on growth would suggest that policy makers pursuing economic growth must create an institutional environment which assures commercial actors that they will be enforce contracts against other private actors at low costs (North 1990). Confidence in the contracting institutions needs to be established.

Sometimes contracts can be self-enforcing; that is, all the actors involved in the transaction are likely to have incentives to honor the contract. Monitoring and enforcement costs are less relevant in such cases. It is important to recognize that self-enforcing contracts are not the norm in commercial exchanges for reasons such as incomplete contracting (contracting actors cannot ex ante specify all the contingencies and how these actors might deal with them) and heterogeneity among actors which makes it difficult to rely on cultural norms to enforce contracts. For most transactions, commercial actors require governmental and sometimes non-governmental agents to enforce contracts. In this article, we examine how the presence of multinational corporations in the host economy might encourage host governments to supply a low cost contracting environment. Given the public good characteristics of the contracting institutions, all commercial actors in the local economy stand to benefit from a more efficient contracting environment.

Why should multinationals care about the contracting environment? Contracts can be enforced via variety of mechanisms. Depending on their competencies, market actors are likely to vary in their preferences for the different modes of contract enforcement. Some actors might prefer enforcement via ethnic networks, others via the mafia, and yet others via the government. As "foreign" actors, multinational corporations are less likely to rely on non-governmental networks to enforce commercial contracts simply because they are embedded in fewer numbers of such networks or do not have the social capital to mobilize these networks for contract enforcement. We speculate that multinationals are likely to

${ }_{1}$ http://law.freeadvice.com/general_practice/contract_law/contract_agreement.htm. 
encourage, sometimes demand, the host governments to supply low cost enforcement environment because this is contract enforcement mode that best coheres with their competencies and penalizes them the least for their foreignness. Let us be very clear: multinationals are self-interested actors that seek to establish a low costs contracting environment to serve their interests. What is important from a policy perspective is that in doing so, multinationals create positive externalities for other commercial actors as well. This sort of contracting mode is not only suitable for multinationals but eventually for all actors that wish to participate in the modern economy. In sum, there are positive social consequences when multinationals pursue private interests in relation to the supply of low cost contracting environment.

Just because some actors seek a desirable policy, governments need not necessarily supply it for reasons such as organizational inertia, resource constraints, or because some domestic actors do not want governments to do so. What might encourage governments to respond to the wishes or demands of multinationals? Two mechanisms might be at work here. First, multinationals can directly encourage host governments to supply contracting institutions that enable them to enforce commercial contracts against private parties at a low cost. They might suggests, request, or demand changes in contract law, better enforcement of existing law, changes in judicial or administrative procedures that can facilitate low cost enforcement. They might do so via local chambers of commerce, business roundtables, joint commissions, and various other forums. We speculate that host governments that depend on FDI for critical resources or that are unwilling to send negative signals to world investors are likely to be more responsive to multinationals' wishes. However, domestic political opposition to multinationals is likely to dampen governments' responsiveness. Therefore, the governments can be expected to weigh the pros and cons to the desire of the multinational corporations for low cost contract enforcement environment.

Second, multinationals might seek to put pressure on the government via the network of suppliers and distributors they work with. The concept of a rent chain (Baron 2000) is relevant here. FDI often stimulates the emergence of new domestic firms which supply materials and distribute its products. Michael Porter (1985) termed this as the value chain network. The political consequences of such value chain networks are significant. The financial interests of these networked firms can be expected to be broadly similar to those of the parent firm simply because they partake the "rents" or profits that the parent firm generates. For example, an important political resource for the automobile companies is their dealer network. Auto dealers have a vested interest in the financial well being of the auto company whose products they distribute. Any policy that benefits/harms the auto company is likely to benefit/harm them as well. With such interest convergence, it is not surprising that foreign auto companies, in particular, have successfully mobilized their "rent chain" to convey their opposition to the Congress regarding policies that discriminate against foreign cars. Japanese automakers have been quite successful on this count. The implication is that to gauge the political resources of any company, including multinational, policy scientists need to take into account the political resources at the disposal of all businesses that are dependent on the parent firm. Thus, the presence of FDI's rent chain networks may alter the political payoffs for governments to supply more efficient contracting institutions. ${ }^{2}$

\footnotetext{
2 The push for formal contracting relationship can come from unlikely sources as well. Many multinationals now require their suppliers to subscribe to international quality and environmental standards such as ISO 9000 and ISO 14001 (Guler et al. 2002) which requires formalizing of many practices. This move toward formalization is likely to nudge such supplier to move from systems of informal contracting to formal contracting.
} 
In order to systematically study the relationship between FDI and host countries' contracting environment, we examine a cross section of 98 developing countries. Our dependent variables originate from the World Bank's Lex Mundi project (Djankov et al. 2003; World Bank 2005a). This unique dataset provides detailed descriptions of two fundamental types of contracting disputes that take place in any commercial environment: debt collections and property evictions. The Lex Mundi data are more micro oriented and specifically address the private contracting environment, unlike other data ${ }^{3}$ that are primarily concerned with the macro contracting environment as captured by the threat of government expropriation. Indeed, much of the literature on property rights and development focuses on the threat of expropriation by the government (North and Weingast. 1989; Barro 1996; Weimer 1997). In the field of international business, this expropriation threat is discussed in the "obsolescing bargain" (Vernon 1971) and "political risk analysis" (Kobrin 1982; Levy and Spiller 1996) literatures. Our focus is on how FDI is associated with the contracting environment that bears upon the division of rents among private actors instead of the contracting environment that influences the division of rents between governments and the multinationals.

We believe taken together the indicators reported by the Lex Mundi dataset serve as reasonable proxies for the overall contracting environment that commercial actors negotiate on a daily basis. Indeed, this is one of the few studies which explore the link between FDI inflows with micro-level contract enforcement practices in host economies. Furthermore, unlike much of the existing global public policy literature which examines how FDI inflows respond to variations in host countries' contracting environments, our article explores how FDI influences host countries' contracting environment. By doing, we hope to focus scholarly interest on the broader issue of the political and distributional consequences of FDI, as opposed to the dominant focus on the institutional preconditions for attracting FDI inflows.

We focus on developing countries for both theoretical and empirical reasons. Unlike developing countries, most developed countries tend to have fairly well-functioning contracting institution. Second, the levels of accumulated inward stock of FDI vary significantly across developing countries. We therefore expect that the consequences of FDI for host contracting institutions to also vary accordingly. Indeed, much of literature on the relationship between FDI and economic development focuses on developing countries (Moran et al. 2005). Empirically, recent work suggests that the pooling of developing with developed countries is not the correct strategy for FDI research simply because the pooled coefficients (with dummies for developing countries) may misrepresent true relationship of FDI with the response variable under study (Blonigen and Wang 2005). Thus, we focus on developing countries only.

The remainder of the article is divided into three parts. The next section outlines the literature we draw upon and describes our theoretical propositions. We then describe the data marshaled to explore our argument and present primary results as well as alternate specifications. The last section outlines our conclusion and identifies areas for future research.

\section{Theoretical perspectives}

Contracts specify rights and obligations of the transacting parties and enable impersonal exchange over space and time. Contracts also bear directly on the organization of

\footnotetext{
${ }^{3}$ For example, variables reported by the Fraser Institute and the Heritage Foundation.
} 
investment and productive activity. If firms can be modeled as a "nexus of contracts" (Jensen and Meckling 1976), we should look to the contracting environment to help explain the existence of FDI. Indeed, international business (Dunning 1981) and international trade scholars (Caves 1996) have developed models to explain conditions under which firms prefer FDI over exports as a vehicle to tap foreign markets and garner access to foreign resources. FDI is a specific organizational choice made by investing firms to take advantage of opportunities for earning profits in the host country and in response to the challenges posed by the contracting environment of the host country (e.g., Dunning's Internationalization variable in the OLI framework).

In the introduction, we briefly discussed various forms of economic globalization. Sometimes, globalization critics incorrectly equate portfolio capital (hot money) with FDI. They represent different category of capital flows having different implications for the economies that host them. Unlike portfolio flows, FDI tends to be less mobile in that it cannot move from one country to another quickly and at a low cost. This necessitates firms undertaking FDI to think in terms of long-term investment in the local economy. The added complication is that given their foreignness (Kostava and Zaheer 1999), multinationals are less likely to be able to draw on ethnic networks to resolve contractual disputes involving private commercial transactions. Instead, we speculate that such firms are likely to turn to state institutions for enforcing contracts. ${ }^{4}$

While there is a substantial literature to explain how host country institutions influence the location, amount, entry mode, and timing of FDI, the literature on how FDI might affect host country political institutions remains relatively underdeveloped (Boddewyn and Brewer 1994). We recognize that there is a literature on the impact of FDI on host country institutions and practices such as human rights (Meyer 1996), corruption (Larrain and Tavares 2004), child labor (Neumayer and de Soysa 2005), environmental practices (Prakash and Potoski 2007), and local government budgets (Figlio and Blonigen 2000). Nevertheless, much of the recent scholarship tends to treat host institutions as the independent variable that shapes various dimensions of FDI (Jensen 2003; Li and Resnick 2003). We suggest that FDI is likely to have incentives to influence domestic institutions simply because it is less mobile than portfolio capital. Following Hirschman (1970), we suggest that if actors cannot "exit" easily or at low costs, they have the incentive to exercise "voice" with the objective to shape the institutional environment to suit their interests. ${ }^{5}$ The strength of their "voice" depends on their salience in the local economy and the level to which the host economy depends on them for its foreign exchange requirements.

In pursuing policy or institutional change, governments face conflicting pressures from a variety of constituents. It is very likely that governments seeking to, say, change the contract law may encounter pressures from other societal actors whose interests are served by the status quo or who simply might have an ideological aversion to FDI. The protest in India by Swadeshi Jagran Manch (http://swadeshi.org/) against multinationals, and their insistence that domestic policies and laws not be changed to accommodate foreign capital, is a case in point. We contend that governments will be more prone to supply contracting institutions which lower the cost of enforcement and of resolving contracting disputes when: (1) FDI plays a larger role in the economy; (2) governments are more dependent on

\footnotetext{
4 Although MNC-host government relations are increasingly conditioned by a slew of bilateral and multilateral investment treaties (UNCTAD 1998, 1999), such inter-governmental treaties may not always bear upon the contracting environment faced by multinationals in dealing directly with private actors.

5 In addition, multinationals may also seek to mandatory arbitration clauses in their contracts with the objective to ensure speedier resolution of such contracting disputes.
} 
international financial markets; and (3) governments are more open to political contestation.

We expect the costs of contract enforcement in developing countries to vary with the levels of FDI. In addition to creating economic and technological externalities for the domestic economy, FDI provides the critical link for domestic capital formation and for bridging balance of payment deficits. The implication is that multinationals' political leverage is likely to vary with governments' dependence on them. Host government dependence will not only be a function of the magnitude of FDI, but also of the exposure of governments to broader international capital markets. Specifically, governments of highly indebted countries will be especially sensitive to FDI in two ways. First, as debt servicing eats up a greater portion of foreign exchange, FDI provides much needed hard currency. Second, developing countries face closer scrutiny by international capital markets (Mosley 2003) leading to more direct volatile responses in capital flows (Ahlquist 2006) and interest rates (Sobel 1999). Not accommodating multinationals sends a negative signal to market actors. The more enmeshed in international capital markets, particularly through debt instruments, the more responsive governments will be to multinationals.

While host governments' responsiveness may be conditioned by the macro political institutions that structure the policy process, prior research provides conflicting conclusions regarding whether democracies or authoritarian systems provide a more hospitable institutional environment to multinationals. Marxists (Hymer 1976; Lenin 1999) and dependency scholars (O'Neal 1994) suggest that authoritarian regimes will be more responsive. For them, FDI and foreign trade are instruments employed by the wealthier countries to exploit developing countries. Because multinationals' profitability is contingent on suppressing labor costs in the host economies, multinationals are likely to form alliances with the local elite to use government resources instrumentally in this regard. Given the close alliance, local elites are likely to be responsive to multinationals' interests in creating a low cost contracting environment.

Other scholars are less pessimistic about multinationals' relationships to host economy politics. They suggest that multinationals are likely to prefer democratic institutions over authoritarian ones because democratic systems offer more opportunities to multinationals to lobby and influence public policy. Jensen (2003) argues that democratic institutions reduce the risks that governments will renege on their bargains either via expropriation or adverse policy change. After all, an authoritarian government strong enough to suppress domestic dissent may well be powerful enough to expropriate rents generated by unprotected foreign investors (Greif et al. 1994; North and Weingast 1989). Arguably, democracies are better able to make credible commitments to rein in their opportunism (North and Weingast 1989; Weingast 1995). Further, because FDI is positively associated with economic growth (but see Janeba 2001), electoral competition creates incentives for governments to supply contract enforcement institutions that favor multinationals. In sum, prior research reaches conflicting conclusions regarding the relationship between domestic institutions and the influence of multinationals on the policy process. We, therefore, believe that this issue needs to be resolved empirically.

Based on the above discussion, we propose the following empirical hypotheses:

Hypothesis 1 Lower enforcement costs will be associated with higher levels of FDI in previous periods, ceteris paribus.

Hypothesis 2 More indebted countries will be more likely to respond to the demands of multinationals. FDI and debt will interact to influence contract enforcement costs. 


\section{Data and variables}

Cross-national, comparative studies of the political activities of business are somewhat sparse, primarily due to a lack of reliable data. Data availability and concept measurement become more problematic when one begins to study countries in transition. Much of business political activity in such institutional environments is invisible and often inadequately captured in official statistics or even surveys. While there is a literature examining corporate political activity in the United States (Grier et al. 1994; Hansen and Mitchell 2000; Hart 2001; Quinn and Shapiro 1991), scholars have also examined corporate political activity (Keim and Baysinger 1993) and strategy (Hillman and Wan 2005) in other countries (Alt et al. 1999; Fisman 2001) as well as in a comparative context (Levy and Egan 1998). Ahlquist and Prakash (2008) examine the influence of FDI on the willingness of locals to rely on the formal banking sector, finding that FDI is positively associated with confidence in the banking sector, but only in developing countries.

We have assembled a sizable dataset covering 98 developing countries ${ }^{6}$ that we employ to assess a new series of variables published by the World Bank. While not enabling direct measurement of multinationals' political activities in host countries, these variables permit investigation of more fine-grained regulatory issues. In particular, these data permit direct observation of the cost of contract enforcement across countries.

\section{Dependent variable: cost of contract enforcement}

Our dependent variables originate from the Lex Mundi project (Djankov et al. 2003) made available by the World Bank (2005a). Researchers composed detailed descriptions ${ }^{7}$ of two types of common contract disputes: an attempt to collect a debt and an eviction. Djankov et al. (2003) chose these dispute types because:

[T]hey represent typical situations of default on an everyday contract in virtually every country. The adjudication of such cases illustrates the enforcement of property rights and private contracts in a given legal environment. Second, the case facts and procedural assumptions could be tailored to make the cases comparable across countries. Third, the resolution of these cases involves lower level civil trial courts in all countries (p. 10).

The dispute descriptions were then sent to law firms in over 100 countries. From the responses, the research team developed an estimate of the cost to enforce the contract as a percent of the disputed amount (COST), the number of legal procedures required to successfully assert contractual rights (PROC), and the number of calendar days elapsed from dispute initiation to resolution (DAYS). While these variables do not correspond exactly to the legal environment faced by multinationals in host countries, we believe they adequately capture cross-national variations in contract enforcement costs.

We recognize that while our theoretical story is arguably one of regulatory change, these data are only available for a one-year cross section (2004). Indeed, there are valid concerns about reverse causality (for a discussion, see Acemoglu et al. 2002). We respond

\footnotetext{
${ }^{6}$ Countries were chosen on the basis of the (1) availability of scores on the dependent variable and (2) availability of the covariates over 1990-2003. "Developing countries" are those not considered "wealthy OECD members" according to the World Bank.

7 See the World Bank's Doing Business reports (2005a) and Djankov et al. (2003) for details on the survey development, coding, and analysis.
} 
to this issue by taking averages and lags of all the independent variables to ensure that the purported "causes" are antecedents to the dependent variable. Our confidence in variability of our dependent variables is strengthened because aggregate measures of political institutions (as measured in Polity IV) show non-zero variance in $40 \%$ of the cases for the 1992-2002 period. We believe it is plausible that there is at least as much variance in contracting costs as in democratic institutions over the same period.

There are at least two other extant datasets that purport to measure similar phenomena, the Heritage Foundation's "property rights" variable and the Fraser Institute's "legal system and property rights" variable. Both these data show change in the 1990-2002 period, further bolstering the contention that contracting institutions are not time-invariant during our observational period. Why not then use these other data? There are three reasons. First, these other data are focused on security of property rights with respect to government, whereas we are concerned with the overall environment for contracting amongst all private parties. Second, these other data rely on questionnaires sent to executives at multinationals and the analysis of secondary source material to derive subjective scores, whereas the World Bank data derive from assessments of the legal environment made by experts in the countries in question. Third, both Heritage Foundation and Fraser Institute datasets correlate with our dependent variable only modestly. As a consequence, we are not comfortable using these other variables as proxies or specification checks as they measure constructs that bear only a family resemblance to our dependent variables.

Another contention regarding legal institutions holds that they are essentially determined by colonial and historical legacies (La Porta et al. 1999), and therefore time invariant. If so, the government's ability to supply "good" institutions is constrained by the extant legal system - and some legal systems may be easier to change than others. La Porta and co-authors end up claiming that English legal traditions of common law are most likely to provide for secure property rights and contracting rights. In order to test this claim in the context of enforcement costs, we employ coding of legal traditions of La Porta et al. (1999) to account for historical and colonial legacies. This variable codes countries as having legal institutional origins in the English, socialist French/Spanish (Napoleonic), German, and Scandinavian traditions. We denote this variable LEGAL. ${ }^{8}$ If this variable shows significant explanatory power, then it weakens our argument that FDI has an important influence on the legal institutions that govern contracting rights. If these variables are not significant, it lends further support to the notion that the costs of contract enforcement do in fact vary with FDI.

Independent variables and interactions

All independent variables, unless otherwise noted, are averages or sums over the period 1990-2002. We choose this time window for three reasons. First, we expect many of our independent variables, especially FDI, to have a cumulative and lasting effect over several years. Values of variables immediately prior to 2004 will not adequately capture the nature and timing of their cumulative influence. Second, the 1990s were a time of enormous institutional upheaval with the collapse of the Soviet bloc and subsequent adoption of market institutions in many post-Communist countries. The year 1990 is the earliest date for which it makes sense to consider a sample including the post-Soviet nations. In

\footnotetext{
${ }^{8}$ When examining developing countries, this variable reduces to dummies for English, socialist, and French/Spanish historical roots. German and Scandinavian traditions made no significant inroads into the developing world.
} 
addition, during this period China emerged as a major destination for FDI and numerous developing countries in Asia and Latin America underwent thorough privatization of stateowned enterprises, many of which ended up in the hands of foreign investors. Finally, there were several financial crises in this period that provided further incentive for governments to respond to the preferences of international capital.

Foreign direct investment and debt servicing costs as proportion of exports are our central explanatory variables. We operationalize FDI as the natural log of the sum of net FDI inflows (as \%GDP) over 1990-2002 (FDI). ${ }^{9}$ We take the sum to account for the accumulation of invested capital in a country over this period. Note that net FDI inflows can be negative in a given year if some multinationals divest more of their holdings than others invest. We control for the initial stock of inward FDI (\% GDP) in 1990 as FDI BASE. Data on FDI are taken from the World Development Indicators (World Bank 2005b), while data on FDI BASE are taken from UNCTAD.

In order to measure a country's sensitivity to international capital markets, we use the $\log$ ratio of debt servicing costs to exports (DEBT). ${ }^{10}$ We use this specification of debt load since exports are the source of hard currency for servicing liabilities in the current period. These data are from the WDI. Our theoretical propositions imply that DEBT and FDI should also interact in significant ways to yield lower contracting costs.

\section{Other controls}

We also include a slate of control variables that either appear in the literature or represent plausible counter arguments. We break these apart as international factors (dependence on IMF, dependence on foreign aid) and domestic factors (levels of economic development, legal tradition, environmental groups, and public sector employment).

\section{International controls}

A plausible alternative to our argument is that contracting institutions may be determined by pressure from the IMF or donors rather than by FDI. The IMF routinely requires debtor countries to reform their economic policy and has increasingly made demands about institutional reform. Creating low cost transactional environments are typical features of IMF conditionalities. Following Vreeland (2003), we measure a country's dependence on IMF in terms of number of years it was under IMF agreement between 1990 and 2003. An agreement can be of any sort: a stand-by arrangement, extended funds facility, or structural adjustment/poverty reduction program. The data are from the IMF's Annual Report. We include a measure of aid dependence to account for the leverage of wealthy Western governments in developing countries. Aid dependence (AID) is measured as foreign aid per capita in current \$US averaged over 1990-2002.

\footnotetext{
${ }^{9}$ Since averages and sums are equivalent up to a constant, findings are unchanged by substituting average FDI inflow for sums. We report sums since they intuitively reflect the idea of accumulated influence. We also note that all findings are robust to substituting FDI as a percentage of gross capital formation for FDI/ GDP.

${ }^{10} \mathrm{We}$ also examined total debt/GDP and balance of payment deficits. Our findings are unchanged substituting the total debt measure. The BOP deficit-FDI interaction is appropriately signed but does not achieve traditional significance levels. This makes sense since BOP statistics will already incorporate the results of FDI-induced trade and financing. We therefore find DEBT to be a more reasonable measure of host country sensitivity to international markets.
} 


\section{Domestic controls $^{11}$}

As noted above, there are conflicting expectations regarding FDI, democracy, and the contracting environment. We include a rough proxy for the openness of the political system using the Polity IV dataset (Marshall et al. 2004). While there are several (highly correlated) measures of democracy, political openness, and the like, Polity is uniquely well suited for studying political institutions (Casper and Tufis 2003). We include the 2002 Polity score for each country (POLITY) to account for the actual level of political openness in the most recent period.

Since secure contracting environment is associated with higher levels of economic development (North 1990), we expect wealthier countries to be associated with less expensive contract enforcement, even among developing countries. We, therefore, include the natural log of per capita GDP at purchasing power parity (GDPpc).

While multinationals may favor efficient contracting institutions, other domestic actors may not share the same preferences (Wilson 1980). Clearly, a low cost enforcement environment privileges some actors over others. Hence, we control for the influence of actors that are likely to oppose multinationals in this regard. Two groups are especially important: public sector employees and environmental groups. We look to public sector employees since they are likely to garner rents from expensive contracting. FDI has been associated with privatization of government-owned enterprises as well as deregulation of sectors where government-owned enterprises enjoyed near monopolies. Reliable, cross-national data on public sector unionization and/or employment in state-owned enterprises are scarce. As a proxy, we use the wage bill paid by the central government, reported as a percentage of overall government expenditure, averaged over 1990-2002 (GOV WAGE). This variable is not available for the full cross section, so whenever we use this variable we loose a substantial number of complete observations. This is noted in all the results reported below.

Many environmental groups oppose free trade and multinationals (Lori and Woodall 2003). They argue that FDI abets regulatory races-to-the-bottom and encouraging the migration of 'dirty' industries to developing countries. Some also suggest that by encouraging global consumerism, multinationals are accentuating environmental degradation (Princen et al. 2002). A strong presence of environmental groups is likely to dampen government's responsiveness to multinationals' preferences for low cost enforcement. We measure the cross-national variation in the importance of environmental groups (IUCN) as the number of non-government-associated domestic environmental organizations that report membership in International Conservation Union. Data are for 2004 as reported by the IUCN. Countries not reporting any member organizations are coded as 0 .

\section{Models and findings ${ }^{12}$}

Since firms are most sensitive to monetary incentives, our primary dependent variable is COST. Our initial set of models employs COST, transformed for normality, as the dependent variable. As a secondary specification and a robustness test, we estimate an alternate model using the log number of procedures as the dependent variable. Across specifications, we find evidence that FDI has a consistent negative impact on COST and PROC but this impact is contingent on the level of debt.

\footnotetext{
11 We tried using dummies for Asia, Latin America, Africa, and post-Soviet states but found them to be insignificant. Also not useful were dummies for federal systems and measures of trade exposure.

12 All models estimated using $\mathrm{R}$ version 2.8.0.
} 
Cost of contract enforcement

In Models 1, 2, and 3, we take enforcement cost as our dependent variable. Since cost has only positive values and is right skewed, we take the natural log to transform the variable into something better approximated by the normal distribution. Equation 1 below describes the basic structural relationship.

$$
\mathrm{COST}=\alpha+\beta_{1} \mathrm{FDI}+\beta_{2} \mathrm{DEBT}+\beta_{3}(\mathrm{FDI} * \mathrm{DEBT})+\Sigma\left(\beta_{k} \mathrm{CONROLS}_{k}\right)+\varepsilon .
$$

We estimate this model using a simple linear regression. Since there was some evidence of minor heteroskedasticity, we report White standard errors. Model 1 pools all observations and includes all covariates for which we have good coverage but omits the interaction term. Model 2 includes the interaction of FDI and DEBT. Model 3 includes GOV WAGE, since its inclusion results in the loss of 21 observations. Results for all three models are reported in Table 1.

In Model 1, we see a negative relationship between FDI and COST, consistent with Hypothesis 1. However, moving from Model 1 to Model 2, we get our central finding: the negative and significant interaction term. Note that the linear terms for both FDI and DEBT are no longer significant once we include the interaction term. What's more, comparing Models 1 and 2, Model 2 is clearly preferred on an $R^{2}, F$, and AIC basis.

Interaction terms, however, are often misinterpreted (Brambor et al. 2006, Braumoeller 2004; Friedrich 1982) since both the conditional effect of a quantity of interest and the standard error of this effect are functions of the values taken by the interacting variable. Graphical plots are the most intuitive way to interpret interaction terms. In Fig. 1, we present the conditional coefficient of FDI across different levels of debt, with the

Table 1 OLS estimates of COST on FDI

\begin{tabular}{lccc}
\hline Variable & Model 1 & Model 2 & Model 3 \\
& Estimate (SE) & Estimate (SE) & Estimate (SE) \\
\hline FDI BASE & $0.014(0.011)$ & $0.015(0.010)$ & $0.018(0.013)$ \\
FDI & $-0.11(0.06)$ & $0.47(0.28)$ & $0.38(0.32)$ \\
POLITY & $0.008(0.011)$ & $0.012(0.010)$ & $0.015(0.014)$ \\
DEBT & $-0.13(0.13)$ & $0.55(0.34)$ & $\mathbf{0 . 4 8}(0.43)$ \\
AID & $0.002(0.0023)$ & $-0.000(0.002)$ & $-0.001(0.003)$ \\
GDPpc & $-\mathbf{0 . 3 1}(0.10)$ & $-\mathbf{0 . 3 1}(0.11)$ & $-\mathbf{0 . 3 3}(0.14)$ \\
FDI $\times$ DEBT & - & $-\mathbf{0 . 2 2}(0.11)$ & $-0.19(0.12)$ \\
LEGAL (socialist) & $-0.20(0.25)$ & $-0.18(0.26)$ & $-0.36(0.33)$ \\
LEGAL (French) & $-0.12(0.17)$ & $0.12(0.17)$ & $-0.13(0.22)$ \\
GOV WAGE & - & - & $-0.006(0.010)$ \\
IMF & $0.013(0.017)$ & $0.007(0.018)$ & $-0.003(0.020)$ \\
IUCN & $-0.021(0.014)$ & $-0.012(0.02)$ & $-0.013(0.015)$ \\
$N$ & 98 & 98 & 77 \\
Adjusted $R^{2}$ & 0.28 & 0.32 & 0.31 \\
Omnibus $F$ & $\mathbf{4 . 8}$ & $\mathbf{5 . 2}$ & $\mathbf{4 . 0}$ \\
\hline
\end{tabular}

Countries more dependent on debt and FDI for capital investment have lower contract enforcement costs Note: White standard errors in parentheses. Bolded estimates are significant at the 0.05 level or better and italicized estimates are significant at the 0.10 level or better (two-tailed test). Constant estimated but not reported. See Appendix for details on the variables 


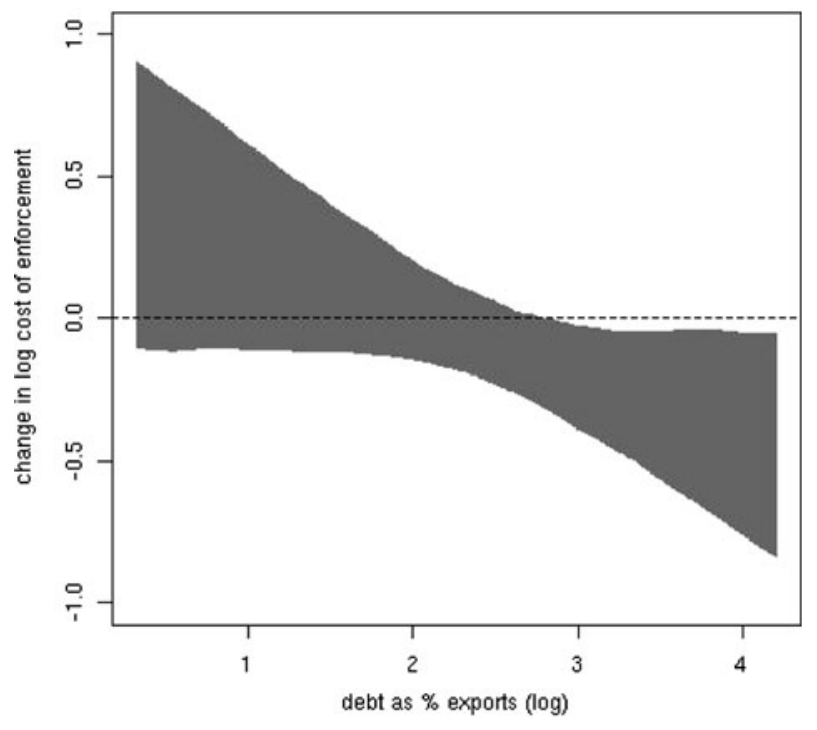

Fig. 1 Conditional effect of FDI on cost. Shaded region represents $95 \%$ confidence interval

associated 95\% confidence interval, taken from Model 2. The effect of FDI is negative and distinguishable from zero at debt servicing levels above $\sim 12 \%$ of exports. At the sample median debt levels, an additional unit of cumulative FDI/GDP in 1990-2002 implies about $1 \%$ lower contract enforcement costs.

In Model 3, we add the government wage bill. While this variable in its own right shows no relationship with COST, its effect on the sample size attenuates some other relationships. Nevertheless, the FDI-DEBT interaction remains at a similar magnitude to Model 2 and is still significant at the 0.1 level.

There are other common findings across specifications that are worth highlighting. BASE FDI, while positive, shows no explanatory power in these models. GDPpc is negative and significant in all specifications, as expected. Wealthier countries, even in the developing world, have more efficient contract enforcement mechanisms. Also immediately noteworthy is that the inclusion of LEGAL — a proxy for institutional legacies-does not show any explanatory power. We therefore do not find support for the notion that contract enforcement costs are a function of historical legacies or broad institutional similarities. Several other controls are found to be unimportant. Aid dependence, the presence of environmental groups, the IMF, and relatively large public sector employment all show no discernable effect on contract enforcement costs across all three samples and specifications of the FDI. Interestingly, we find POLITY to have no significant relationship with COST; democracy does not appear to influence costs of contract enforcement in the developing world once other factors are accounted for.

Specification test: counts of procedures

As a specification test, we examine the robustness of our findings in Table 1 using an alternate operationalization of the dependent variable: the $(\log )$ number of mandated legal procedures parties must engage in to resolve their contracting dispute. We take more procedures required of the litigants to be generally more onerous, but this is an imperfect 
Table 2 OLS estimates of PROC on FDI

Findings in the alternate specifications largely conform to those from Table 2

Note: Bolded estimates are significant at the 0.05 level or better while italicized entries are significant at the 0.1 level (twotailed test). Constant estimated but not reported. See Appendix for details on the variables

\begin{tabular}{lcl}
\hline Variable & Model 4 & \\
\cline { 2 - 3 } & Estimate & SE \\
\hline DAYS & $\mathbf{0 . 3 2}$ & 0.06 \\
FDI BASE & 0.001 & 0.002 \\
FDI & $\mathbf{0 . 0 4}$ & 0.01 \\
POLITY & -0.01 & 0.005 \\
DEBT & 0.001 & 0.004 \\
AID & 0.000 & 0.001 \\
GDPpc & 0.004 & 0.044 \\
FDI $\times$ DEBT & $-\mathbf{0 . 0 0 2}$ & 0.001 \\
LEGAL (socialist) & 0.15 & 0.11 \\
LEGAL (French) & $\mathbf{0 . 2 9}$ & 0.08 \\
IMF & 0.006 & 0.008 \\
IUCN & $\mathbf{0 . 0 1 5}$ & 0.007 \\
$N$ & 97 & \\
Adjusted $R^{2}$ & 0.41 & \\
Omnibus $F$ & $\mathbf{6 . 6}$ & \\
\hline
\end{tabular}

relationship. Procedures could be quick and efficient or drag on for months. Some procedures could require court fees and attorneys while others may not. This imperfect link with cost is reflected in the weak correlation between COST and PROC of 0.19. Procedures are, however, the closest link to the actual institutional rules involved and policies delivered by governments and are therefore of interest in their own right.

We model PROC using standard linear regression. Though this variable is theoretically truncated at zero, no country was observed with fewer than 14 procedures. No statistical model yielded fitted values below zero, so we are comfortable using the OLS framework here, rather than a model based on alternative distributional assumptions. ${ }^{13}$ The models we estimate use the same linear predictor term as Model 2 with the addition of (log) DAYS to control for elapsed time. Findings, reported in Table 2, broadly conform to earlier results; namely that FDI has a negative marginal effect on PROC but only in connection with greater indebtedness. ${ }^{14}$

Consistent with the findings in Models 1-3, the interaction of FDI and DEBT is negative and significant in Model 4. The conditional coefficients and associated standard errors are plotted in Fig. 2. From this plot, we can readily see that the magnitude of FDI's relationship with institutions depends heavily on debt levels. At low debt levels, the effect of FDI is tiny but significantly positive. At debt levels above the third quartile (23\%), the effect is negative but with substantial uncertainty around the estimates. Other results also differ. In particular, the dummy for French legal traditions is significant and positive, though that for socialist traditions remains insignificant. POLITY is now negative and significant. Interestingly, the variable measuring the degree of environmental activism is

\footnotetext{
${ }^{13}$ We also attempted to model PROC as a count process, using DAYS as the observation interval. Both quasi-poisson and negative binomial routines had trouble converging and were quite sensitive to linear transformations on DAYS. We therefore report only OLS results.

14 Note that in this model, we include FDI and DEBT with out the log transformation; the non-logged model fit marginally better in this case. This difference in functional form further underscores the notion that COST and PROC are not measuring the same thing.
} 


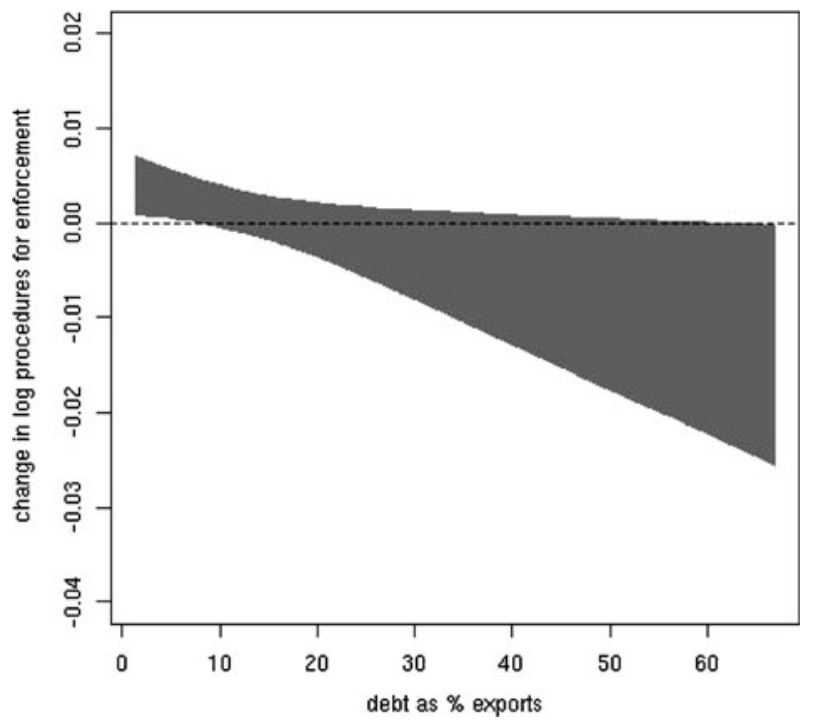

Fig. 2 Conditional effect of FDI on cost (change in log procedures for enforcement vs. debt as \% exports). Shaded region represents $95 \%$ confidence interval

associated with a significant increase in the number of procedures in contract enforcement. We take these findings to reflect the distinction between PROC, as a policy variable, and COST as the price variable most salient to firms. A more granular description of procedures, their costs, and firms' preferences over them would enable us to tease out this relationship further. Clearly, however, this alternate formulation adds support to our hypothesis that multinationals' direct investment activities are associated with a lower cost contracting environment. This relationship is conditioned by the government's exposure to foreign capital markets via debt dependency.

\section{Conclusions}

Is FDI associated with variations in host country contracting environment across a cross section of developing countries? We argue that multinationals have incentives to influence the contracting environment in host countries. Host governments are more likely to respond to multinationals' wishes when they are more dependent on foreign capital markets. Drawing on the World Bank's Lex Mundi dataset (Djankov et al. 2003) on microlevel contracting environment, we find that FDI is associated with lower contract enforcement costs, particularly when the country in question is more indebted. And these results hold across varying model specifications, including a different specification of our dependent variable.

Our article has broader implications for the study and practice of policy sciences. The current economic crisis has focused attention on the tragic social consequences of poorly regulated markets and the unintended consequences of financial globalization. It is noteworthy that unlike the Great Depression which led countries to enact beggar-thy-neighbor polices, governments so far have resisted the demands for protectionist measure. Thus, the institutions of trade-induced globalization seem to have emerged unscathed. Similarly, 
governments have not clamped down on FDI flows. In some ways, these policy choices are indicative of the increased appreciation of the net positive effects of trade-induced and FDI-induced globalization. Our article should be viewed in this broader perspective in that we provide some evidence that the consequences of FDI for this host economy might go beyond the more visible aspects associated with supply of technology and capital. FDI has consequences for the policy environment, specifically, the contracting environment, these consequences tend to be positive. Future work should also identify and empirically examine other sorts of unintended consequences for other dimensions of policy environment including corruption levels and social policies.

Our article raises interesting issues for further research. Broadly, it highlights the under studied puzzles as we being to think of domestic policy institutions as dependent variables and multinationals as drivers of institutional change. Any research in this vein requires a careful study of multinationals' political strategies. While multinationals' political muscle grows with the salience of FDI in the host economy, conscious political agency is required to translate salience into effective political strategy. Future research could study how political or non-market strategies (Baron 2000) of multinationals systematically vary within and across countries, and how this variation translates into political efficacy. In particular, we have treated FDI as homogenous and uniform. This assumption clearly must be relaxed. We believe that both organizational level and structural variables (e.g., asset specificity) will play a crucial role in this regard. Finally, recognizing the limitations of working for a one-year cross-sectional data, our article lays out concrete ideas to test in longitudinal panel studies once data on contracting environment are made available.

Open Access This article is distributed under the terms of the Creative Commons Attribution Noncommercial License which permits any noncommercial use, distribution, and reproduction in any medium, provided the original author(s) and source are credited.

\section{Appendix}

See Tables 3 and 4.

Table 3 Variables in the analysis

\begin{tabular}{|c|c|c|c|c|c|c|}
\hline Var. name & Description & Source & Min. & Max. & Mean & SD \\
\hline COST & $\begin{array}{l}\text { Cost of contract enforcement } \\
\text { (\% debt amount) (2004) }\end{array}$ & World Bank ${ }^{\mathrm{a}} / \mathrm{DLLS}^{\mathrm{b}}$ & 8.1 & 281.7 & 35.5 & 41.6 \\
\hline DAYS & $\begin{array}{l}\text { No. of days for contract } \\
\text { enforcement (2004) }\end{array}$ & World Bank/DLLS & 27 & 1459 & 420.9 & 211.1 \\
\hline PROC & $\begin{array}{l}\text { No. of procedures for contract } \\
\text { enforcement (2004) }\end{array}$ & World Bank/DLLS & 14 & 58 & 33 & 10.9 \\
\hline FDI & $\begin{array}{l}\text { Sum of net FDI inflows (\% } \\
\text { GDP) } 1990-2002\end{array}$ & $\mathrm{WDI}^{\mathrm{c}}$ & 0.34 & 182.4 & 31.5 & 30.5 \\
\hline AID & $\begin{array}{l}\text { Foreign aid per capita, (\$US) } \\
\text { avg. 1990-2002 }\end{array}$ & WDI & -0.12 & 243.7 & 37.3 & 37.0 \\
\hline POLITY & Polity $\mathrm{IV}_{2002}$ & Polity IV & 0 & 20 & 11.8 & 6.6 \\
\hline DEBT & $\begin{array}{l}\text { Debt servicing (\% exports) avg. } \\
\text { 1990-2002 }\end{array}$ & WDI & 1.8 & 66.8 & 17.0 & 10.9 \\
\hline
\end{tabular}


Table 3 continued

\begin{tabular}{|c|c|c|c|c|c|c|}
\hline Var. name & Description & Source & Min. & Max. & Mean & SD \\
\hline GDPpc & $\begin{array}{l}\text { In GDP per capita, PPP (\$US) } \\
\text { avg. 1990-2002 }\end{array}$ & WDI & 6.2 & 9.9 & 7.9 & 0.9 \\
\hline LEGAL & $\begin{array}{l}\text { Legal origin }(1=\text { English, } \\
2=\text { Socialist, } 3=\text { French } / \\
\text { Spanish, } 4=\text { German, } \\
5=\text { Scandinavia })\end{array}$ & $\operatorname{LLSV}^{\mathrm{d}}$ & NA & NA & NA & NA \\
\hline IUCN & $\begin{array}{l}\text { Number of environmental } \\
\text { NGOs reporting membership }_{\text {in IUCN }^{\mathrm{e}}}\end{array}$ & IUCN & 0 & 19 & 3.6 & 4.4 \\
\hline IMF & $\begin{array}{l}\text { Number of years between } 1990 \\
\text { and } 2002 \text { in which a country } \\
\text { is under an IMF agreement }\end{array}$ & $\mathrm{IMF}^{\mathrm{g}}$ & 0 & 12 & 7.1 & 4.5 \\
\hline GOV WAGE & $\begin{array}{l}\text { Wages (\% government } \\
\text { expenditure) }\end{array}$ & WDI & 3.8 & 47.9 & 23.9 & 11.3 \\
\hline FDI BASE & $\begin{array}{l}\text { Inward FDI stock (\% GDP), } \\
1990\end{array}$ & UNCTAD & 0 & 83 & 10.0 & 15.1 \\
\hline
\end{tabular}

${ }^{a}$ World Bank's Doing Business website (2005a)

b Djankov et al. (2003)

c World Bank's World Development Indicators (2005a)

${ }^{\mathrm{d}}$ La Porta et al. (1999)

${ }^{\text {e }}$ Countries with no reporting non-government affiliated organizations were coded as 0

${ }^{\mathrm{f}}$ Following Przeworski and Vreeland (Przeworski and Vreeland 2000; Vreeland 2003), a country-year is counted if the country in question is under any sort of IMF agreement (stand-by agreement, extended funds facility, or structural adjustment/poverty reduction facility)

${ }^{g}$ International Monetary Fund Annual Report (various years)

Table 4 Correlations between variables in Table 1

\begin{tabular}{lrrrrrrrrrr}
\hline & $\begin{array}{l}\text { Cost } \\
(\log )\end{array}$ & $\begin{array}{l}\text { FDI } \\
\text { BASE }\end{array}$ & $\begin{array}{l}\text { FDI } \\
(\log )\end{array}$ & $\begin{array}{l}\text { DEBT } \\
(\log )\end{array}$ & POLITY & AID & $\begin{array}{l}\text { GDPpc } \\
(\log )\end{array}$ & IMF & LEGAL & IUCN \\
\hline Cost $(\log )$ & 1.00 & 0.21 & -0.20 & -0.09 & -0.08 & 0.12 & -0.48 & 0.10 & -0.06 & -0.19 \\
FDI BASE & 0.21 & 1.00 & 0.16 & 0.05 & 0.09 & 0.12 & 0.08 & -0.20 & 0.03 & 0.07 \\
FDI $(\log )$ & -0.20 & 0.16 & 1.00 & -0.12 & 0.19 & 0.10 & 0.22 & 0.14 & -0.12 & -0.06 \\
DEBT & -0.09 & 0.05 & -0.12 & 1.00 & 0.10 & -0.06 & 0.02 & 0.24 & 0.19 & 0.32 \\
$\quad(\log )$ & & & & & & & & & & \\
POLITY & -0.08 & 0.09 & 0.19 & 0.10 & 1.00 & -0.02 & 0.33 & 0.19 & -0.09 & 0.14 \\
AID & 0.12 & 0.12 & 0.10 & -0.06 & -0.02 & 1.00 & -0.30 & 0.41 & 0.07 & -0.19 \\
GDPpc & -0.48 & 0.08 & 0.22 & 0.02 & 0.33 & -0.30 & 1.00 & -0.36 & 0.05 & 0.22 \\
$\quad(\log )$ & & & & & & & & & 0.05 & -0.04 \\
IMF & 0.10 & -0.20 & 0.14 & 0.24 & 0.19 & 0.41 & -0.36 & 1.00 & 0.12 & -0.12 \\
LEGAL & -0.06 & 0.03 & -0.12 & 0.19 & -0.09 & 0.07 & 0.05 & 0.12 & 1.00 & -0.10 \\
IUCN & -0.19 & 0.07 & -0.06 & 0.32 & 0.14 & -0.19 & 0.22 & -0.04 & -0.10 & 1.00 \\
\hline
\end{tabular}




\section{References}

Acemoglu, D., \& Johnson, S. (2005). Unbundling institutions. The Journal of Political Economy, 113(5), 949-995. doi:10.1086/432166.

Acemoglu, D., Johnson, S., \& Robinson, J. (2002). Reversal of fortune: Geography and institutions in the making of the modern world income distribution. The Quarterly Journal of Economics, 117(4), 12311294. doi:10.1162/003355302320935025.

Ahlquist, J. S. (2006). Economic policy, institutions, and capital flows: Portfolio and direct investment flows in developing countries. International Studies Quarterly, 50, 687-710. doi:10.1111/j.1468-2478. 2006.00420.x.

Ahlquist, J., \& Prakash, A. (2008). The influence of foreign direct investment on contracting confidence in developing countries. Regulation \& Governance, 2(3), 316-339. doi:10.1111/j.1748-5991.2008. 00040.x.

Alt, J. E., Carlsen, F., Heum, P., \& Johansen, K. (1999). Asset specificity and the political behavior of firms: Lobbying for subsidies in Norway. International Organization, 53(1), 99. doi:10.1162/002081899 550823.

Baron, D. (2000). Business and public policy (3rd ed.). Upper Saddle River, NJ: Prentice Hall.

Barro, R. (1996). Democracy and growth. Journal of Economic Growth, 1(1), 1-27. doi:10.1007/BF00 163340 .

Blonigen, B. A., \& Wang, M. G. (2005). Inappropriate pooling of wealthy and poor countries in empirical FDI studies. In T. Moran, E. Graham, \& M. Blomstrom (Eds.), Does FDI promote development?. Washington, DC: Institute for International Economics.

Boddewyn, J. J., \& Brewer, T. L. (1994). International-business political behavior: New theoretical directions. Academy of Management Review, 19(1), 119-143. doi:10.2307/258837.

Brambor, T., Clark, W. R., \& Golder, M. (2006). Understanding interaction models: Improving empirical analyses. Political Analysis, 14(1), 63-82. doi:10.1093/pan/mpi014.

Braumoeller, B. F. (2004). Hypothesis testing and multiplicative interaction terms. International Organization, 58, 807-820. doi:10.1017/S0020818304040251.

Casper, G., \& Tufis, C. (2003). Correlation versus interchangeability: The limited robustness of empirical findings on democracy using highly correlated data sets. Political Analysis, 11, 196-203. doi: $10.1093 / \mathrm{pan} / \mathrm{mpg} 009$.

Caves, R. E. (1996). Multinational enterprise and economic analysis (2nd ed.). Cambridge: Cambridge University Press.

Djankov, S., La Porta, R., Lopez-de-Silanes, F., \& Shleifer, A. (2003). Courts: The Lex Mundi Project. The Quarterly Journal of Economics, 118, 453-517. doi:10.1162/003355303321675437.

Dunning, J. H. (1981). International production and the multinational enterprise. Boston: Allen and Unwin.

Figlio, D. N., \& Blonigen, B. A. (2000). The effects of foreign direct investment on local communities. Journal of Urban Economics, 48, 338-363. doi:10.1006/juec.2000.2170.

Fisman, R. (2001). Estimating the value of political connections. The American Economic Review, 91, 1095-1102.

Friedrich, R. J. (1982). In defense of multiplicative interaction terms in multiple regression equations. American Journal of Political Science, 26(4), 797-833. doi:10.2307/2110973.

Greif, A., Milgrom, P., \& Weingast, B. (1994). Coordination, commitment, and enforcement: The case of merchant guilds. The Journal of Political Economy, 102(4), 745-776. doi:10.1086/261953.

Grier, K., Munger, M., \& Roberts, B. (1994). The determinants of industrial political activity, 1978-1986. The American Political Science Review, 88, 911-926. doi:10.2307/2082716.

Guler, I., Guillen, M., \& MacPherson, J. M. (2002). Global competition, institutions, and organizational change: The international diffusion of the ISO 9000 quality standards. Administrative Science Quarterly, 47, 207-232. doi:10.2307/3094804.

Hansen, W. L., \& Mitchell, N. J. (2000). Disaggregating and explaining corporate political activity: Domestic and foreign corporations in national politics. The American Political Science Review, 94(4), 891-903. doi: $10.2307 / 2586214$.

Hart, D. M. (2001). Why do some firms give? Why do some give a lot? High-tech PACs, 1977-1996. The Journal of Politics, 63(4), 1230-1249. doi:10.1111/0022-3816.00108.

Held, D., \& McGrew, A. (Eds.). (2003). The global transformation reader (2nd ed.). Cambridge: Polity Press.

Hillman, A. J., \& Wan, W. P. (2005). The determinants of MNE Subsidiaries' political strategies: Subsidiary, parent, and host country effects. Journal of International Business Studies, 36, 332-340.

Hirschman, A. (1970). Exit, voice, and loyalty: Responses to decline in firms, organizations, and states. Cambridge, MA: Harvard University Press. 
Hymer, S. (1976). The international operations of national firms: A study of direct foreign investment. Cambridge: The MIT Press.

International Monetary Fund. (various years). Annual report. Washington, DC: International Monetary Fund.

Janeba, E. (2001). Attracting FDI in a politically risky world. Cambridge: National Bureau of Economic Research.

Jensen, N. M. (2003). Democratic governance and multinational corporations: Political regimes and inflows of foreign direct investment. International Organization, 57(3), 587. doi:10.1017/S0020818303573040.

Jensen, M., \& Meckling, W. H. (1976). The theory of the firm: Managerial behavior, agency costs and ownership structure. Journal of Financial Economics, 3(October), 305-360. doi:10.1016/0304405X(76)90026-X.

Keim, G. D., \& Baysinger, B. D. (1993). The efficacy of business political activity. In B. M. Mitnick (Ed.) Corporate political agency. Newbury Park, CA: Sage.

Kobrin, S. (1982). Managing political risk assessment. Berkeley: University of California Press.

Kostava, T., \& Zaheer, S. (1999). Organizational legitimacy under complexity. Academy of Management Review, 24(1), 64-81. doi:10.2307/259037.

La Porta, R., Lopez-de-Silanes, F., Andrei, S., \& Vishny, R. W. (1999). The quality of government. Journal of Law Economics and Organization, 15, 222-279. doi:10.1093/jleo/15.1.222.

Larrain, F., \& Tavares, J. (2004). Does foreign direct investment decrease corruption? Cuadernos de Economia, 41, 217-230.

Lenin, V. I. (1999). Imperialism: the highest stage of capitalism (online). Melbourne: Resistance Books.

Levy, D. L., \& Egan, D. (1998). Capital contests: National and transnational channels of corporate influence on the climate change negotiations. Politics \& Society, 26(3), 337-361. doi:10.1177/00323292980 26003003.

Levy, B., \& Spiller, P. (1996). Regulations, institutions, and commitment: Comparative studies of telecommunications. Cambridge: Cambridge University Press.

Li, Q., \& Resnick, A. (2003). Reversal of fortunes: Democratic institutions and foreign direct investment inflows to developing countries. International Organization, 57(1), 175-211.

Lori, W., \& Woodall, P. (2003). Whose trade organization?. New York: WW Norton.

Marshall, M. G., Jaggers, K., \& Gurr, T. R. (2004). Polity IV. College Park, Maryland: University of Maryland.

Meyer, W. H. (1996). Human rights and MNCs. Human Rights Quarterly, 18, 368-397. doi:10.1353/hrq. 1996.0020.

Moran, T., Graham, E. M., \& Blomstrom, M. (Eds.). (2005). Does foreign direct investment promote development?. Washington, DC: Institute for International Economics.

Mosley, L. (2003). Global capital and national governments. Cambridge: Cambridge University Press.

Neumayer, E., \& de Soysa, I. (2005). Trade openness, foreign direct investment and child labor. World Development, 33(1), 43-63. doi:10.1016/j.worlddev.2004.06.014.

North, D. C. (1981). Structure and change in economic history. New York: Norton.

North, D. C. (1990). Institutions, institutional change and economic performance. New York: Cambridge University Press.

North, D. C., \& Weingast, B. (1989). Constitutions and commitment: The evolution of institutions governing public choice in 17th century England. The Journal of Economic History, 69(4), 803-832.

O'Neal, J. R. (1994). The affinity of investors for authoritarian regimes. Political Research Quarterly, 47(3), $565-588$.

Olson, M. (2000). Power and prosperity: Outgrowing communist and capitalist dictatorships. Oxford: Oxford University Press.

Porter, M. E. (1985). Competitive advantage. New York: Free Press.

Prakash, A., \& Hart, J. A. (Eds.). (1999). Globalization and governance. London: Routledge.

Prakash, A., \& Potoski, M. (2007). Investing Up. FDI and the cross-national diffusion of ISO 14001. International Studies Quarterly, 51(3), 723-744. doi:10.1111/j.1468-2478.2007.00471.x.

Princen, T., Maniates, M. F., \& Conca, K. (Eds.). (2002). Confronting consumption. Cambridge: MIT Press.

Przeworski, A., \& Vreeland, J. R. (2000). The effect of IMF programs on economic growth. Journal of Development Economics, 62, 385-421. doi:10.1016/S0304-3878(00)00090-0.

Quinn, D. P., \& Shapiro, R. Y. (1991). Business political power: The case of taxation. The American Political Science Review, 85(3), 851-874. doi:10.2307/1963853.

Sobel, A. C. (1999). State institutions, private incentives, global capital. Ann Arbor: University of Michigan.

UNCTAD. (1998). Bilateral investment treaties in the mid-1990s. New York: United Nations. 
UNCTAD. (1999). Trends in international investment agreements: An overview, UNCTAD series on issues in international agreements. New York: United Nations.

Vernon, R. (1971). Sovereignty at Bay: The multinational spread of U.S. enterprises. New York: Basic Books.

Vreeland, J. R. (2003). The IMF and economic development. New York: Cambridge University Press.

Weimer, D. (Ed.). (1997). The political economy of property rights. Cambridge: Cambridge University Press.

Weingast, B. (1995). The economic role of political institutions: Market preserving federalism and economic development. Journal of Law Economics and Organization, 11(1), 1-31.

Wilson, J. Q. (1980). The politics of regulation. New York: Cambridge University Press.

World Bank (2005a). Doing business. Cited May 1, 2005, from http://rru.worldbank.org/DoingBusiness/.

World Bank (2005b). World development indicators [CD-ROM]. World Bank. 